\title{
PENGARUH PELAYANAN MA RAUDLATUT THALIBIN TERHADAP KEPUASAN SISWA TAHUN AKADEMIK 2017 / 2018
}

\author{
Rizka Mahendra Putra \\ Email : rizkamahendraputra08@gmail.com
}

\begin{abstract}
Abstrak
Kepuasan pembeli tergantung pada kinerja karyawan dalam pemenuhan harapan pembeli. Pelayanan menjadi cara untuk menarik minat dan memberikan suatu kepuasan kepada pelanggan, yang mana hal tersebut dapat diukur oleh kepuasan konsumen. Kepuasan merupakan perasaan senang atau kecewa seseorang yang muncul setelah membandingkan kinerja produk yang dipikirkan terhadap kinerja yang diharapkan jika kinerja berada dibawah harapan, pelanggan tidak puas, jika kinerja memenuhi harapan, pelanggan puas, jika kinerja melebihi harapan, pelanggan amat puas. Penelitian ini bertujuan untuk mengetahui apakah ada pengaruh pelayanan MA Raudlatut Thalibin terhadap kepuasan siswa. Penelitian ini merupakan penelitian kuantitatif, metode pengumpulan data menggunakan metode angket, dokumenter, observasi dan interview. Subjek penelitian ini adalah siswa MA Raudlatut Thalibin dari kelas X samapai dengan kelas XII dengan jumlah populasi sebanyak 30 siswa. Analisis data menggunakan software computer statistical package for Social Scinece (SPSS) versi 17,0 for windows. Uji hipotesis untuk mengetahui pengaruh pelayanan MA Raudlatut Thalibin terhadap kepuasan siswa dengan hasil Fhitung $=2502,886668>$ Ftabel $=$ 4,195971707 maka H0 ditolak atau Ha diterima. Atau bisa juga dengan membandingkan nilai P-value $=0,000<\alpha=0,05$, maka Ha diterima oleh karena itu pelayanan MA Raudlatut Thalibin berpengaruh terhadap kepuasan siswa. persentase pelayanan MA Raudlatut Thalibin menurut hasil output sebesar 98,9\%, persentase pelayanan MA Raudlatut Thalibin tersebut menunjukkan bahwa pengaruh pelayanan MA Raudlatut Thalibin terhadap kepuasan siswa pengaruhnya sangat tinggi dapat diartikan pelayanan MA Raudlatut Thalibin terhadap kepuasan siswa mempunyai sumbangan efektif sebesar 98,9\%. Kepuasan siswa dapat disimpulkan berasal dari pelayanan MA Raudlatut Thalibin yang baik dalam proses pembelajaran ataupun kegiatan-kegiatan lainnya.
\end{abstract}

Kata kunci: Pelayanan MA Raudlatut Thalibin, Kepuasan siswa 


\begin{abstract}
Satisfaction of the buyer depends on the employee's performance in meeting the expectations of buyers. Services to be a way to attract and provide a satisfaction to customers, which it can be measured by customer satisfaction. satisfaction of a person's feelings of pleasure or disappointment that emerged after comparing the performance of the products considered against the expected performance if the performance is below expectations, the customer is not satisfied, if the performance meets expectations, the customer is satisfied, if performance exceeds expectations, the customer is very satisfied. This study aims to determine whether there is influence MA Raudlatut Thalibin services to student satisfaction. This research is a quantitative study, the method of data collection using questionnaires, documentary, observation and interviews. The subjects were students of MA Raudlatut Thalibin class X until to class XII with a population of as many as 30 students. Data analysis using SPSS version 17.0 for windows. Hypothesis testing to determine the effect of MA Raudlatut Thalibin services to student satisfaction with the results of $F=$ $2502.886668>F=4.195971707$ then $\mathrm{HO}$ is rejected or accepted Ha. Or it could be by comparing the P-value $=0.000<\alpha=0.05$, then the $H$ a received therefore MA Raudlatut Thalibin services affect student satisfaction percentage of MA Raudlatut Thalibin services according to the results output by $98.9 \%$, the percentage of MA Raudlatut Thalibin service is suggests that the effect of MA Raudlatut Thalibin services to a very high student satisfaction effect can be interpreted MA Raudlatut Thalibin services to the satisfaction of students having the effective contribution of $98.9 \%$. Student satisfaction can be derived from services deduced MA Raudlatut Thalibin are either in the process of learning or other activities.
\end{abstract}

\title{
Keywords : MA Raudlatut Thalibin Administration, Student Satisfaction.
}




\section{PENDAHULUAN}

\section{Latar Belakang}

Kualitas suatu bangsa sangat ditentukan oleh faktor pendidikan. Peran pendidikan sangat penting untuk menciptakan kehidupan yang cerdas, damai, terbuka dan demokratis. Oleh karena itu, pembaharuan pendidikan harus selalu dilakukan untuk meningkatkan kualitas pendidikan nasional. Pelayanan merupakan faktor penting dalam memenuhi kepuasan pembeli sebagai konsumen. Hal ini sesuai dengan pemikiran (Kotler, 2000:177-178) kepuasan pembeli tergantung pada kinerja karyawan dalam pemenuhan harapan pembeli. Pelayanan menjadi cara untuk menarik minat dan memberikan suatu kepuasan kepada pelanggan, yang mana hal tersebut dapat diukur oleh kepuasan konsumen. Teori ini didukung oleh pendapat (Kotler, 2000: 177) dimana kepuasan merupakan perasaan senang atau kecewa seseorang yang muncul setelah membandingkan kinerja produk yang dipikirkan terhadap kinerja yang diharapkan jika kinerja berada dibawah harapan, pelanggan tidak puas, jika kinerja memenuhi harapan, pelanggan puas, jika kinerja melebihi harapan, pelanggan amat puas.

Hasil survey dari penelitian yang dilakukan oleh (Srinadi. A dan Nilakusumawati. E.) Berdasarkan kelima faktor penentu kepuasan terhadap pelayanan fakultas yaitu faktor tangible, reability, responsivenees, assurance, dan empathy. Apabila diperlukan skala prioritas dalam upaya peningkatan mutu pelayanan, maka faktor reability yang terlebih dahulu ditingkatkan, karena memberikan pengaruh dominan dalam menentukan kepuasan mahasiswa terhadap pelayanan FMIPA Unud sebagai lembaga pendidikan. Selain faktor penting dalam memenuhi kepuasan, pelayanan juga cara untuk menarik minat dan memberikan kepuasan pelanggan, sama halnya dengan di lembaga pendidikan baik sekolah maupun perguruan tinggi. Pelayanan di sebuah lembaga dapat terlihat dan diukur oleh kepuasan para pelanggan yang menjadi konsumen di lembaga tersebut. Keberhasilan prodi sebagai unit kerja dalam perguruan tinggi sangat ditentukan oleh pelayanan yang diberikan, dimana pelayanan yang baik dapat diidentifikasi melalui kepuasan pelanggan, dalam hal ini adalah siswa. Banyak faktor yang menentukan pelayanan dalam bidang pendidikan MA Raudlatut Thalibin sehingga dibutuhkan suatu analisis yang dapat melihat pengaruh tersebut secara keseluruhan.

Dari uraian diatas, peneliti tertarik untuk melakukan penelitian tentang "pengaruh pelayanan MA Raudlatut Thalibin terhadap kepuasan siswa”. 


\section{Rumusan Masalah}

Berdasarkan latar belakang masalah diatas, maka rumusan masalahnya adalah: "Apakah ada pengaruh pelayanan terhadap kepuasan?"

\section{Definisi Operasional Variabel}

Untuk menyamakan persepsi antara peneliti dan pembaca maka perlu dirumuskan Definisi Operasional Variabel dalam penelitian ini, variabel penelitiannya ada 2 yaitu kepuasan, dan pelayanan. Pelayanan (X1) merupakan suatu bentuk kinerja seseorang, yang dihadapkan dengan pelanggan. Kepuasan (Y) suatu bentuk rasa senang atau kecewa seseorang terhadap apa yang diinginkan-nya.

\section{Tujuan Penelitian}

Tujuan penelitian adalah merupakan target yang hendak dicapai melalui kegiatan penelitian untuk menemukan, mengembangkan atau menguji kebenaran suatu pengetahuan. Adapun tujuan yang ingin penulis capai dalam penelitian ini adalah untuk mengetahui Pengaruh pelayanan MA Raudlatut Thalibin terhadap kepuasan siswa.

\section{KAJIAN TEORITIS}

\section{Pelayanan MA Raudlatut Thalibin}

1. Pengertiang Pelayanan

Pelayanan merupakan faktor penting dalam memenuhi kepuasan pembeli sebagai konsumen. Hal ini sesuai dengan pemikiran (Kotler, 2000:177-178) kepuasan pembeli tergantung pada kinerja karyawan dalam pemenuhan harapan pembeli. Pelayanan menjadi cara untuk menarik minat dan memberikan suatu kepuasan kepada pelanggan, yang mana hal tersebut dapat diukur oleh kepuasan konsumen. Pentingnya memberikan pelayanan yang berkualitas disebabkan pelayanan (service) tidak hanya sebatas mengantarkan atau melayani. (Thorik G. dan Utus H., 2006:77). Pelayanan berarti mengerti, memahami, dan merasakan sehingga penyampaiannyapun akan mengenai heart share konsumen dan pada akhirnya memperkokoh posisi dalam mind share konsumen. Dengan adanya heart share dan mind share yang tertanam, loyalitas seorang konsumen pada produk atau usaha perusahaan tidak akan diragukan.

Salah satu dimensi kualitas pelayanan adalah tangibles (bukti langsung) yang berupa fasilitas fisik meliputi gedung, dan sarana prasarana lainnya. Kualitas pelayanan juga dapat dilihat dari responsiveness (daya tanggap) karyawan, yang mana karyawan memiliki kemauan dan memberikan pelayanan yang cepat dan tepat kepada pelanggan. Memberikan pelayanan yang cepat dan tepat menunjukkan pelaku bisnis yang 
professional. Thorik G. dan Utus H. (2006:115) menjelaskan bahwa dalam soul marketing kecepatan dalam bergerak adalah utama. Pemanfaatan waktu secara efektif benar-benar menjadi hal yang bersifat esensial. Kualitas pelayanan guru juga dapat dilihat dari faktor empathy (empati) yang dapat diberikan oleh karyawan kepada pelanggan/konsumen. Sikap empati ditunjukkan melalui kemudahan dalam melakukan hubungan, komunikasi yang baik, perhatian pribadi, dan memahami kebutuhan para pelanggan.

\section{Pengertian Kepuasan Konsumen (Siswa)}

Kotler (2000:177) berpendapat bahwa dimana kepuasan merupakan perasaan senang atau kecewa seseorang yang muncul setelah membandingkan kinerja produk yang dipikirkan terhadap kinerja yang diharapkan. Jika kinerja berada dibawah harapan, pelanggan tidak puas, jika kinerja memenuhi harapan, pelanggan puas, jika kinerja melebihi harapan, pelanggan amat puas. Hal ini didukung oleh Scotti (2007) yang menemukan bahwa kualitas pelayanan berhubungan dengan kepuasan konsumen. Kepuasan pelanggan sebagai suatu tanggapan emosional pada evaluasi terhadap pengalaman konsumsi suatu produk atau jasa Wilkie (dalam Tjiptono, 1997) dalam tatugasakhir.blogspot.com/2007/. Kepuasan konsumen merupakan perbedaan antara yang diharapkan konsumen (nilai harapan) dengan situasi yang diberikan perusahaan (MA Raudlatut Thalibin) didalam usaha memenuhi harapan konsumen (siswa).

Sedangkan bertemunya harapan konsumen dengan pelayanan yang diberikan perusahaan merupakan penerimaan kualitas pelayanan itu sendiri, sehingga dapat disimpulkan yang dimaksud dengan kepuasan konsumen adalah besarnya tingkat penerimaan kualitas pelayanan yang diberikan oleh perusahaan kepada konsumen. Sebuah perusahaan dikatakan bijaksana kalau mengukur kepuasan pelanggan secara teratur, karena kunci untuk mempertahankan pelanggan adalah kepuasan (Kotller, 2000:179). Pelanggan yang sangat puas umumnya: lebih lama setia, membeli lebih banyak ketika perusahaan memperkenalkan produk baru dan meningkatkan produksi yang ada, membicarakan hal-hal yang menyenangkan tentang perusahaan dan produknya, tidak banyak memberi perhatian pada merek pesaing dan tidak terlalu peka terhadap harga, menawarkan ide produk atau layanan kepada perusahaan, dan lebih sedikit biaya untuk melayani pelanggan ini daripada baru karena transaksinya bersifat rutin.

\section{Pengaruh Pelayanan Terhadap Kepuasan}

Pelayanan berpengaruh terhadap kepuasan konsumen (siswa). Hal ini didukung oleh teori yang dikemukakan oleh Scotti (2007) yang menemukan bahwa kualitas 
pelayanan berhubungan dengan kepuasan konsumen. (Kotler, 2000:177-178) kepuasan pembeli tergantung pada kinerja karyawan dalam pemenuhan harapan pembeli. Kepuasan konsumen merupakan fenomena setalah pembelian (Giese \& Cote, 2000). Maksudnya bahwa kepuasan konsumen terjadi setelah pembelian, dimana konsumen setelah melakukan pembelian kemudian akan melakukan evaluasi terhadap produk tersebut apakah sesuai dengan harapannya atau tidak. Apabila kinerja produk sesuai dengan harapan maka konsumen akan merasa puas. Sebaliknya, bila kinerja produk tidak sesuai dengan harapan maka konsumen akan merasa tidak puas.

Lupiyoadi (2001) mengatakan bahwa kualitas produk merupakan salah satu faktor yang mempengaruhi kepuasan konsumen. Pelayanan menjadi cara untuk menarik minat dan memberikan suatu kepuasan kepada pelanggan, yang mana hal tersebut dapat diukur oleh kepuasan konsumen. Jadi dari beberapa teori yang diungkapkan diatas bahwa pelayanan sangat berpengaruh terhadap kepuasan konsumen. Dalam hal ini yang dimaksudkan adalah pelayanan MA Raudlatut Thalibin berpengaruh terhadap kepuasan siswa.

\section{Kajian Empiris}

Kepuasan mahasiswa dipengaruhi oleh banyak faktor, salah satunya adalah pelayanan. Diana Rahmawati (Jurnal Pendidikan Akuntansi Indonesia VII. 02. 18-32), hasil penelitian ini menunjukkn bahwa kualitas pelayanan pegawai administrasi berpengaruh terhadap kepuasan mahasiswa di lingkungan FISE UNY. Hasil tersebut sesuai dengan kajian teori yang telah di kemukakan sebelumnya bahwa kualitas pelayanan mempengaruhi kepuasan. Hasil penelitian ini juga didukung oleh penelitian yang dilakukan oleh Scotti yang menemukan bahwa kualitas pelayanan berhubungan dengan kepuasan konsumen. Kepuasan konsumen terjadi jika konsumen menggunakan kembali layanan dan menyarankan orang lain untuk menggunakan layanan tersebut.

Berdasarkan penelitian ini mengimplikasikan bahwa puas tidaknya mahasiswa terhadap pelayanan yang diberikan tergantung pada kualitas pelayanan yang dibrikan oleh pegawai administrasi dilingkungan FISE UNY. Sehingga pimpinan fakultas hendaknya meningkatkan kualitas pelayanan pegawai administrasi dengan peningkatan kegiatan pendidikan dan pengembangan pegawai administrasi dalam hal pelayanan kepada mahasiswa. Hal ini ditunjukkan dengan nilai koefisien 0,787333 nilai t-value sebesar 41,072917 dan nilai p-value sebesar 0,0000. 


\section{METODE PENELITIAN}

\section{Rancangan Penelitian}

Dalam penelitian ini metode rancangan penelitian yang digunakan adalah rancangan "Ex Post Facto", menurut Nana Sudjana dan Ibrahim (1999:56) menjelaskan "Ex Post Facto tersebut mewujudkan perwujudan atau manipulasi variabel $\mathrm{X}$ (variabel bebas) yang telah terjadi sebelumnya sehingga penelitian tidak perlu memberikan perlakuan lagi, tinggal melihat efeknya terhadap variabel terikat". Sedangkan Moh. Nasir (1999:66) menyatakan pendapatnya mengenai rancangan penelitian ini bahwa " $E x$ Post Facto adalah penyelidikan secara empiris yang sistematis dimana penelitian tidak mempunyai kontrol terhadap variabel-variabel bebas karena meninfestasi fenomena telah terjadi atau fenomena sukar manipulasi”.

Rancangan penelitian yang digunakan berkaitan dengan masalah yang muncul dari judul yang telah ditetapkan. Hal ini dijelaskan oleh Nana Sudjana dan Ibrahim (1999:66) bahwa "Ex Post Facto dapat dilakukan apabila peneliti telah yakin bahwa perlakukan variabel bebas telah terjadi sebelumnya. Metode ini banyak digunakan dalam bidang pendidikan, sebab tidak semua masalah pendidikan dapat diteliti dengan metode eksperimen".

\section{Metode Penentuan Daerah Penelitian}

Daerah penelitian adalah merupakan daerah yang digunakan peneliti dalam melakukan penelitian. Adapun metode yang digunakan dalam penelitian ini adalah Purposive Sampling Area. "Metode purposive adalah merupakan metode penentuan daerah penelitian yang segaja dan berdasarkan ciri-ciri sifat populasi yang sudah diketahui sebelumnya" (Hadi, 2001:82).

Dari pendapat di atas dapat disimpulkan bahwa dalam penelitian ini untuk menentukan daerah penelitian menggunakan metode "Porposive Sampling Area" yaitu di MA Raudlatut Thalibin Sumberkolak Situbondo yang terletak di Jalan cempaka no 2.

\section{Metode Penentuan Responden}

Dalam menentukan responden penelitian, peneliti dalam hal ini mengacu pada beberapa pendapat: Menurut Winarno Surahmad (1996:20) menyatakan bahwa "responden adalah orang-orang yang dapat memberikan responsive terhadap masalah yang diteliti baik populasinya maupun sampel "Sedangkan Sutrisno Hadi (1999:2) menyatakan bahwa "Banyak responden harus dipertimbangkan waktu, tenaga dan biaya".

Pendapat lain disampaikan oleh Suharsini Arikunto (1996:107) yang menyatakan 
sebagai berikut: "Untuk sekedar ancer-ancer, maka subyeknya kurang dari 100 diambil samua, sehingga penelitinya merupakan penelitian populasi, selanjutnya jika jumlah subyeknya besar dapat diambil antara $10-15 \%$ atau lebih.

\section{Metode Pengumpulan Data}

Untuk memperoleh data-data yang positif, peneliti menggunakan metode pengumpulan data sebagai bahan informasinya, suatu penelitian akan berjalan baik apabila data yang diperoleh dan dikumpulkan efektif serta relevan. Menurut pendapat Bimo Walgito (1998:51) bahwa "Pengumpulan data adalah merupakan salah satu hal yang sangat penting dalam pendidikan”. Sedangkan menurut Abdullah (1996:13) menjelaskan bahwa "Pengumpulan data adalah merupakan kegiatan dalam rangka pelaksanaan program bimbingan di sekolah".

Dari penjelasan kedua pendapat di atas, penulis dapat simpulkan bahwa metode pengumpulan data adalah suatu cara yang dipergunakan dalam usaha untuk memperoleh keterangan atau data untuk penelitian. Di dalam penelitian ini penulis menggunakan metode pengumpulan data sebagai berikut:

1. Metode Angket

2. Metode Dokumenter

3. Metode Observasi

4. Metode Interview

\section{Teknik Analisis Data}

Dalam menganalisa data-data hasil penelitian, peneliti akan menguji dengan menggunakan metode statistik, karena data yang diperoleh berupa angka-angka. Sedangkan untuk menganalisa data itu peneliti menggunakan rumus Analisa Regresi.

\section{DESKRIPSI HASIL PENELITIAN}

Pada bagian ini dijelaskan mengenai distribusi jawaban responden terhadap variabel-variabel dalam penelitian ini yaitu mengenai pengaruh pelayanan MA Raudlatut Thalibin terhadap kepuasan siswa yang disusun dalam tabel distribusi frekuensi sebagai berikut:

1. Pelayanan MA Raudlatut Thalibin (X)

Pada penelitian ini, pelayanan MA Raudlatut Thalibin dapat di ukur dengan menggunakan indikator Reliability (kehandalan karyawan), Empathy (empati), Tangible (bukti langsung), Responsiveness (daya tanggap), Aasurance (jaminan). Dari indikatorindikator tersebut dibuat 20 pertanyaan dengan skor 1-5 dari tiap pertanyaan. Hal tersebut sesuai dengan alternatif jawaban yang ada dalam penelitian ini. Berdasarkan 
data tersebut panjang kelas interval dapat ditentukan melalui selisih nilai skor tertinggi dikurangi skor terendah dan ditambah dengan 1, hasilnya dibagi dengan banyak kelas interval. Perhitungan panjang kelas interval tersebut adalah sebagai berikut:

\begin{tabular}{|c|c|c|c|c|}
\hline No & Interval & Kategori & $f$ & $\%$ \\
\hline 1 & $69-75$ & $\begin{array}{l}\text { Sangat Tidak } \\
\text { Setuju }\end{array}$ & 1 & 3,33 \\
\hline 2 & $76-82$ & Tidak setuju & 1 & 3,33 \\
\hline 3 & $83-89$ & Kurang Setuju & 9 & 30 \\
\hline 4 & $90-96$ & Setuju & 14 & 46,67 \\
\hline \multirow[t]{2}{*}{5} & $97-103$ & Sangat setuju & 5 & 16,67 \\
\hline & \multicolumn{2}{|r|}{ Jumlah } & 30 & 100 \\
\hline
\end{tabular}

Berdasarkan hasil perhitungan data di atas, maka dapat dibuat grafik histogram frekuensinya sebagai berikut:

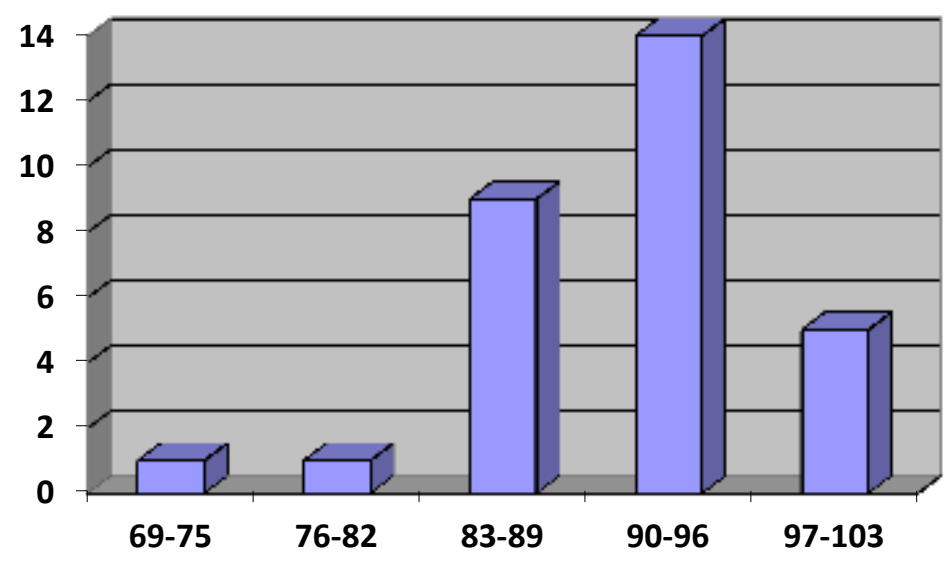

Dari table di atas, diketahui bahwa untuk pelayanan MA Raudlatut Thalibin dengan interval 69-75, 3,33\% dari 30 siswa, 1 siswa menjawab sangat tidak setuju, interval 76 - 82 sebesar 3,33\% dari 30 siswa, 1 siswa menjawab tidak setuju, interval 83 - 89 sebesar $30 \%$ dari 30 siswa, 9 siswa menjawab kurang setuju. Interval 90 - 96 sebesar 46,67\% dari 30 siswa, 14 siswa menjawab setuju, Interval 97 - 103 sebesar $16,67 \%$ dari 30 siswa, 5 siswa menjawab sangat setuju, sehingga dapat disimpulkan sebagian besar siswa menjawab setuju yang berarti pelayanan MA Raudlatut Thalibin berhasil memuaskan siswa. 
2. Kepuasan Siswa MA Raudlatut Thalibin (Y)

Kepuasan siswa MA Raudlatut Thalibin dapat dilihat dari hasil angket yang di berikan kepada siswa. Kriteria tersebut dapat diukur melalui indikator-indikator kepuasan. Berdasarkan hasil penelitian, didapat data tentang Kepuasan siswa setelah mendapat pelayanan dari MA Raudlatut Thalibin dengan skor tertinggi 110 dan skor terndah 76 pada lampiran.

\begin{tabular}{|c|c|c|c|c|}
\hline No & Interval & Kategori & $f$ & $\%$ \\
\hline 1 & $76-82$ & Sangat Tidak Setuju & 1 & 3,33 \\
\hline 2 & $83-89$ & Tidak Setuju & 1 & 3,33 \\
\hline 3 & $90-96$ & Kurang Setuju & 7 & 23,33 \\
\hline 4 & $97-103$ & Setuju & 16 & 53,34 \\
\hline \multirow[t]{2}{*}{5} & $104-110$ & Sangat Setuju & 5 & 16,67 \\
\hline & \multicolumn{2}{|r|}{ jumlah } & 30 & 100 \\
\hline
\end{tabular}

Berdasarkan hasil perhitungan data di atas, maka dapat dibuat grafik histogram frekuensinya sebagai berikut:

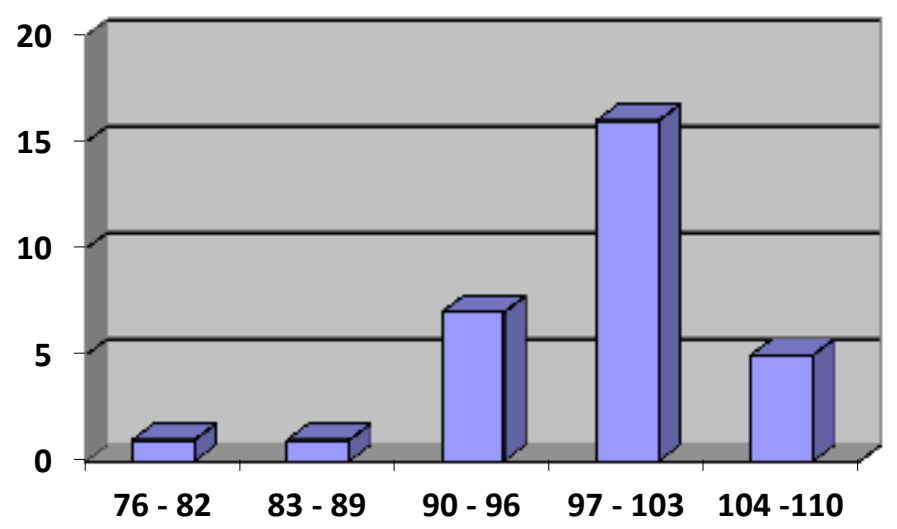

\section{Uji Hipotesis}

Untuk mengetahui pengaruh pelayanan MA Raudlatut Thalibin terhadap kepuasan siswa secara parsial, maka menggunakan uji f. Uji pengaruh ini dilakukan dengan rumusan hipotesis sebagai berikut:

1. $\mathrm{H}_{0}$ : tidak ada pengaruh pelayanan MA Raudlatut Thalibin terhadap kepuasan siswa

2. $\mathrm{H}_{\mathrm{a}}$ : ada pengaruh pelayanan MA Raudlatut Thalibin terhadap kepuasan siswa

Fhitung $=2502,886668>$ Ftabel $=4,195971707$ maka $\mathrm{H0}$ ditolak atau Ha diterima. Atau bisa juga dengan membandingkan nilai $\mathrm{P}$-value $=0,000<\alpha=0,05$, maka 
Ha diterima oleh karena itu pelayanan MA Raudlatut Thalibin berpengaruh terhadap kepuasan siswa.

\section{KESIMPULAN}

Ada pengaruh yang sangat kuat antara pelayanan MA Raudlatut Thalibin terhadap kepuasan siswa Sumberkolak Kabupaten Situbondo tahun pelajaran 2017/2018. Dengan diperoleh nilai F hitung $=2502,88668$. Untuk F tabel dengan taraf signifikansi sebesar 5\%, diperoleh nilai $\mathrm{F}$ tabel $=4,195971707$. Perbandingan keduanya memberikan hasil: Fhitung > Ftabel (2502,88668 > 4,195971707). Dengan demikian, dapat disimpulkan bahwa kepuasan siswa dipengaruhi oleh pelayanan MA Raudlatut Thalibin.

\section{DAFTAR PUSTAKA}

Frans. 2011. Strategi Sukses Memasarkan Produk Baru. Jakarta: Gramedia

Hadi, Sutrisno. (2004). Metodologi Research, Yogyakarta; Andi

Kotler P. Manajemen Pemasaran. New Jersey: Pearson Education, Inc 2006.

Lambrie I. Manajemen Anggaran Berbasis Kinerja. LaksBang PRESSindo, Yogyakarta 2011.

Martono, Nanang. (2010). Metode Penelitian Kuantitatif Analisis Isi dan Analisis Data Sekunder, Jakarta: PT RajaGrafindo Persada

Nawari. (2010). Analisis Regresi dengan MS Excel 2007 dan SPSS 17, Jakarta: PT Elex Media Komputindo

Oentoro D. Manajemen Pemasaran Modern. LaksBang PRESSindo, Yogyakarta 2010.

Pramana T. Manajemen risiko Bisnis. Sinar Ilmu Publishing 2011

Rahmawati D. Pengaruh Pemanfataan Teknologi Informasi Terhadap Kualitas Pelayanan Pegawai Administrasi Dan Pengaruh Kualitas Pelayanan Pegawai Administrasi Terhadap Kepuasan Mahasiswa Di Lingkungan FISE UNY. Jurnal Pendidikan Akuntansi Indonesia. VIII. 02. 18-29

Setyosari, Punaji. (2010). Metode Penelitian Pendidikan dan Pengembangan. Jakarta: Kencana

Srinadi, G. A. M., Nilakusumawati, D. P. E. 2008. Faktor-faktor Penentu Kepuasan Mahasiswa Terhadap Pelayanan Fakultas Sebagai Lembaga Pendidikan. Cakrawala Pendidikan. XXVII. 03. 217-231 
Sugiyono. (2012). Statistik nonparametris, Bandung: Alfabeta

Sugiyono. (2010). Metode Penelitian Pendidikan Pendekatanm Kuantitatif, Kualitatif, dan $R \& D$. Bandung: Alfabeta

Sulistyo, Joko. (2010). 6 Hari Jago SPSS 17, Yogyakarta: Cakrawala

Supeli A. Manajemen Pemasaran Global. Center Por Society Studies (CSS), Tegal Gede Jember 2010.

Supriansyah, Haris. (2009). Buku Pintar Microsoft Office Excel Seri Junior Programmer, Gedung Bumi Padjadjaran: OASE Media. 